\title{
RUSSIAN LANGUAGE AS A MEANS OF ACCULTURATION: DEVELOPMENT OF RUSSIAN-FOREIGN SCHOOLS IN THE ORENBURG REGION IN THE MIDDLE OF THE XIX CENTURY
}

(C) 2018

\author{
Lyubichankovskiy Sergey Valentinovich, doctor of historical sciences, professor, \\ head of History of Russia Department \\ Orenburg State Pedagogical University (Orenburg, Russian Federation)
}

\begin{abstract}
The paper analyzes the main development trends of the so-called «Russian-foreign» schools in the Orenburg Region in the middle of the XIX century. The author shows that five primary Russian-Kyrgyz schools functioned in the Orenburg Region in the early 1860s. The Orenburg archive material drawn to the analysis showed that up to the introduction of the «Rules» of 1870 there was no well-thought-out policy and system for education in the foreign environment in the Russian Empire. The paper concludes that the administration of the region initiated the creation of schools for «foreigners» with a compulsory study of the Russian language long before these «Rules». This was a feature of the Orenburg Region, connected with its border and border position. It is proved that the educational institutions for «foreigners» that arose on the territory of the Orenburg Region were brought to life by the needs of the regional administration in translators and lower employees. The conclusion is made that the problem of counteracting «tatarization» (changing the identity of the Kazakh inhabitants of the Orenburg province to the Tatar one) was extremely important for the regional administration. In addition the border authorities needed Kazakhs who knew the Russian language because they were interested in establishing a stable communication with the inhabitants of the steppe. It is proved that in the Orenburg Region there has been a systematic, well-thought-out course for creating a system of «foreigners» training only since the 1870 s.

Keywords: Orenburg Region; Russian Empire; Kazakh Steppe; Central Asia; Central Asia; acculturation; Russian language; foreigners; Russian-foreign schools; regional administration; Tatars; Ural; Volga Region; national policy.
\end{abstract}

УДК 94 (470) "1885/1917" : 371.4-058.12

Статья поступила в редакцию 01.10.2017

\section{ВЫРАЩИВАНИЕ РЕВОЛЮЦИОНЕРА: КОНЦЕПЦИЯ «СВОБОДНОГО ВОСПИТАНИЯ» В ЭЛИТНЫХ ШКОЛАХ РОССИИ КОНЦА ХІХ - НАЧАЛА ХХ ВЕКА}

(C) 2018

\author{
Веременко Валентина Александровна, доктор исторических наук, профессор, \\ заведующий кафедрой истории России \\ Ленинградский государственный университет имени А.С. Пушкина \\ (г. Пушкин, г. Санкт-Петербург, Российская Федерации)
}

Аннотация. В статье исследуется влияние педагогической концепции «свободного воспитания» на формирование мировоззрения подростков из дворянско-интеллигентских семей России конца XIX - начала $\mathrm{XX}$ в. Обращается внимание на то, что в полной мере данная педагогическая установка могла быть реализована лишь в элитных учебных заведениях. Делается вывод, что «новые идейные родители» и «передовые школы» осуществляли единый воспитательный подход, ориентированный на формирование особой интеллигентской оппозиционности, принимающей, а то и поддерживающей все средства в борьбе «граждан» за «свободу». Несмотря на то, что группа «новых идейных родителей» не могла составлять к началу XX в. действительно массового явления, она тем не менее распространяла свое влияние как на остальное образованное население страны, так и на министерство народного просвещения, которое в угоду передовой педагогике соглашалось на повсеместное внедрение отдельных идей «свободного воспитания» в средней школе. В результате целенаправленных усилий семьи и школы молодежь с ранней юности втягивалась в политическую деятельность, что становилось одним из существенных факторов революционизации российского общества.

Ключевые слова: Россия; начало ХХ века; дворянство; интеллигенция; «единство семьи и школы»; «свободное воспитание»; гражданское воспитание; подростки; элитные учебные заведения; педагоги; «новые идейные родители»; оппозиционность; революционизация.

В пореформенный период в дворянско-интеллигентской среде России появляется и постепенно занимает существенное место группа «новых идейных родителей», ставивших целью воспитание из своих детей свободных, гармоничных личностей, «людей и граждан»; формирование в каждом из них «внутреннего человека», способного к самостоятельному и сознательному принятию любых решений, нравственно, физически и умственно развитой персоны [1, c. 36-37]. Понимая, что доверить подобную миссию чужим людям невозможно, «новые идейные родители», как отцы, так и матери, считали необходимым Самарский научный вестник. 2018. Т. 7, № 1 (22) самостоятельно заниматься воспитанием своих детей, проводя с ними по несколько часов в день, руководя играми, ведя беседы, проверяя уроки и т.д. [2].

Вкладывая душу и силы в детей, такие родители с ужасом думали о том, как все их усилия будут «похоронены» в старой казенной школе, подвергавшейся неустанной критике «передовой общественности». Прежде всего государственные учреждения обвиняли в том, что они нравственно разлагает молодежь: «К сожалению, наша, особенно средняя школа, вследствие многих серьезных недостатков прививает крупные нравственные недостатки детям, как то: 
лживость, равнодушие к умственным занятиям, апатичность, беспринципность, леность, слабость воли, невежественное самомнение, теоретичность и беспочвенность мировоззрения и проч. ...» [3, с. 117]. Развращая душу, школа, как отмечалась, не думает и о теле, и ее питомцы, получая аттестаты и дипломы, одновременно выходят из ее стен «комками нервов с атрофированными руками, паразитами человечества, не умеющими посадить дерево, развести себе огород, запрячь лошадь, затопить печь, починить сапог, сварить себе поесть, не умеющими даже убрать за собой» [4, с. 109]. Вместо знающих и любящих детей педагогов там работали, как отмечали сами учащиеся в анкетах, «машины», которые, осуществляя «вялое», «неумелое» и «скучное» преподавание, «худо», «резко» и «грубо» обращались со своими подопечными, «за всякий пустяк оговаривали», «очень ругали и много наказывали», «чертыхались да орали на весь класс» «скверными словами» и даже «дрались» [5]. Вывод напрашивался сам собой: «Скучная, отвратительная школа! Ненавистная тюрьма! Как это только решаются отрывать ребенка от живой среды...» [6, c. 34]. И «новые идейные родители» не решались..

K концу XIX в. среди «передовых» педагогов и «ответственных» родителей окончательно сформировался тот идеал школы, который первые стремились создать, а вторые хотели получить. Следует подчеркнуть, что и те, и другие рассматривали новую школу не как досужие мечты, а как вполне осуществимое и своевременное (если не запоздавшее) мероприятие: «Время для создания новой школы давно наступило: и лучшее доказательство этого в том, что казавшиеся прежде неосуществимыми педагогические утопии Руссо и Толстого начинают то тут, то там мало-помалу приходить в жизнь, а сама жизнь, - с другой стороны, - наталкивает людей, желающих свободно работать в области воспитания и просвещения, к созданию как раз именно тех форм и видов просветительного общения, которые близко подходят и часто прямо осуществляют некоторые из основных идей Руссо и Толстого, и прежде всего их основную идею свободы» [7, с. 83].

Итак, в основу идеала была положена идея «свободного воспитания», предполагавшая «создание условий для спонтанного саморазвития личности ребенка, не искажающих заложенных в нем потенциальных возможностей» [8, с. 185]. При этом обучение должно было «иметь в виду» подготовить «не специалистов, а просвещенных людей (выделено в источнике - прим. авт.)» [9, с. 30-31]. Но самое главное - при сохранении «первостепенных нравственных требований к личности, составляющих суть всякого идеала и исходящих от общенациональных моральных ценностей и понятий, содержание его разрослось вследствие выделения гражданских качеств личности как ее главных нравственных свойств» [10, c. 213]. Таким образом, данный воспитательный подход предполагал формирование граждан, способных к участию в общественной жизни и считавших его необходимым. В этом плане воспитательные задачи, которые ставили перед собой «новые идейные родители» и «передовые педагоги», оказывались тождественными, а это, в свою очередь, способствовало реализации еще одного педагогического принципа «единство семьи и школы». Если же «семья и школа не готовы к активному участию в общественной жизни, - повторяли апологеты новой школы, - то такое воспитание не является в социально-педагогическом отношении эффективным» [11, с. 49]. Исходя из таких установок, новая школа должна была способствовать включению «учащейся молодежи в самоуправление и политическую деятельность по совершенствованию государственного устройства» [12, с. 58].

Итак, начиная поиск «правильной» школы для своего ребенка, «новые идейные родители» имели возможность познакомиться с работами отечественных педагогов и получить максимально возможную информацию о недостатках казенной школы и о достоинствах «свободной». Но, переходя от теоретических рассуждений к реальной практике, родители должны были принимать решение, учитывая помимо педагогических еще и массу других факторов [13].

Первый вопрос, который вставал перед семьей, ищущей учебное заведение для ребенка, состоял в том, «стоит ли терпеть «казенное образование» ради аттестата, гарантирующего возможность поступления в высшее учебное заведение»? Как ни горько это было признать сторонникам «свободной» школы, но часть родителей не решалась отказаться от казенного учебного заведения потому, что «оно дает диплом; диплом же этот, в свою очередь, дает права, ради приобретения которых он поступил или родители отдали его сюда» $[14$, с. 234]. Понимая, что это серьезный аргумент, передовые педагоги доказывали, что как раз отсутствие прав и есть главное достоинство новой школы: «А между тем, стоит только изменить эту коренную фальшь в постановке наших учебных заведений, стоит только отнять у средней школь все ее права и преимущества (выделено в источнике прим. авт.), и картина изменится радикально, и недавние враги превратятся в друзей и союзников». Отказ от прав - вот средство, которое уничтожает формализм, присущий школе: «Ученики будут видеть в школе только то, что она есть и чем должна быть - средством получить образование и приобрести необходимые ему те или иные специальные познания, в учителях только помощников и руководителей на этом трудном пути. Отношения с ними из принудительных и обязательных превратятся в добровольные и свободные» [14, с. 235].

Если для родителей дворянских мальчиков, в семьях которых традиционно все мужчины посвящали себя государственной службе, решение о предпочтении «свободной школы» казенной давалось с большим трудом, то намного проще было сделать соответствующий выбор в отношении девочек, так как они могли рассчитывать на поступление в университет только с 1905 г., да и то лишь в качестве вольнослушательниц [15]. В результате, исходя из запроса родителей, передовые школы в массе своей открывались как женские, совместные или коммерческие учебные заведения, в которых наряду с детьми наиболее «прогрессивных» дворян за одной партой сидели дети евреев, ограниченные при поступлении в государственную школу процентной нормой и разбогатевших представителей других сословий, которые и не предполагали продолжать образование в российских университетах.

Отказ от сословных привилегий оценивался сторонниками теории свободного воспитания как важ- 
ный шаг по пути к мирному переходу к новому обществу. К.Н. Вентцель, С.Т. Шацкий, В.Н. Шацкая, С.Н. Дурылин и другие доказывали, что с помощью правильного воспитания возможно и даже необходимо осуществить мирное переустройство современной им действительности, преодолеть грани между различным социальными стратами, осуществить кооперацию всех классов общества [8, с. 184-185].

Вместе с тем эти «свободные», «непривилегированные» школы, ориентированные на «единение» общества на деле сразу оказывались элитными, так как высокие требования к организации образования, с одной стороны, и отсутствие государственного финансирования - с другой, предполагали значительную стоимость обучения. Так, например, школа Е.С. Левицкой в Царском Селе - одна из первых средних школ с совместным обучением мальчиков и девочек - сразу заявила о себе как об учебном заведении «продвинутого типа», предназначенном для узкого круга детей «избранных родителей». В данном учебном заведении обещали «полную свободу ребенка», «строгий семейный режим», «хорошее образование, присмотр и благотворное влияние детей разных полов». Все это стоило далеко не дешево: с пансионеров взималась плата в размере 820 р., а приходящие должны были вносить 300 р., причем в эту сумму не входили уроки музыки, латинского языка и танцев [16-17].

Элитность школы закреплялась не только стоимостью, но и условиями поступления. С одной стороны, официальные требования к поступающим в подобные школы были значительно выше, чем в казенные, но с другой - вокруг «передовых» учебных заведений быстро формировался свой кружок «сочувствующих», в который входили друзья, родственники и знакомые учащих, для детей которых возможны были определенные поблажки, а родителям дозволялось несколько задержать оплату. Вот, например, как проходил вступительный экзамен в Стоюнинскую гимназию для О. Яфы, мать которой уже несколько лет до этого была в приятельских отношениях с хозяйкой учебного заведения. Сама владелица - М.Н. Стоюнина, «обласкав, самолично проэкзаменовала меня по русскому языку, арифметике и Закону Божию (письменно - в классе, устно - в учительской) и найдя мои знания и навыки вполне удовлетворительными (какие-то недочеты, впрочем, обнаружились в приемах устного счета, которые мама обещала восполнить за лето), - сказала, что зачислит меня в список учениц будущего I класса» [18, л. 90].

Выбранная родителями «правильная» школа могла располагаться далеко от места жительства семьи, но и это обстоятельство, как правило, не останавливало «новых идейных родителей», готовых идти ради воспитания ребенка на любые неудобства и значительные расходы. Так, для того, чтобы упомянутая выше Оленька Яфа могла быстро добираться до школы, вся семья переехала из «удобной, большой и светлой», да к тому же и достаточно дешевой квартиры, в «неудобную, маленькую, сырую» и более дорогую, но расположенную на соседней улице с гимназией [18-19]. Дети старшего подросткового возраста, даже если речь идет о молодых девушках 1517 лет, могли обучаться в школе, расположенной в 40-50 мин. езды, добираясь до нее с несколькими пересадками на конке, извозчике, а позднее и на трамваях. Подобную дорожную эпопею переживала ежедневно, например, ученица старших классов Катя Кавос. «Погода все время очень скверная, бежать ей утром нужно до Благовещенской площади, там садиться на 4-й номер; но это в теории так, а на практике выходит, что она всякий раз берет извозчика» (любящая поспать девочка все время просыпала и опаздывала). В итоге мать решила: «чем ей по мокроте бежать до извозчика, уж лучше пускай ей подает всякий день мой знакомый, весьма порядочный старичок, и мы с тобой будем покойнее и стоит тот же полтинник» [20, л. 49]. Но если семья милостиво разрешила подвозить девочку в школу, то обратно она должна была добираться сама: «Возвращаюсь ... на двух трамваях (причем всегда все страшно толкаются и пихаются; воздух в вагонах невыносимый, воняет сапогами, водкой и т.д.)» [21, л. 96 об.-97]. Характерно, что оба приведенных примера касаются С.-Петербурга. Очевидно, что в столице Российской империи, с ее десятками женских средних учебных заведений, можно было найти школу, не требующую подобных жертв...

Значительно сложнее было найти подходящее учебное заведение родителям, которые проживали в провинции и не могли переселиться в крупные города, но и не хотели отдавать ребенка в пансион [22], а уж тем более селить его на квартире чужих людей. В этом случае оставался один вариант - оставлять ребенка на домашнем обучении, но данная стратегии противоречила идеи «новых идейных родителей» о необходимости социализации ребенка. Нередко такая альтернатива завершалась решением отправить детей в казенное учебное заведение. Вот, например, какие своеобразные плюсы обучения в традиционной школе находила одна из «новых» матерей: «... Я теперь прихожу к заключению, что я правильно решила, отдав его в гимназию. В воспитательном отношении она дает массу вредного и решительно ничего хорошего, но как приготовление к жизни, как фактор, помогающий складываться в душе ребенка такому отношению к жизни, при котором она становится возможной, гимназия незаменима. Если бы Боря продолжал учиться дома до старших классов: 7-8го, как я хотела, то, при уединенности нашей семьи от общества, ему пришлось бы только в этих классах познакомиться с отрицательными сторонами жизни, и, может быть, с непривычки к ним (ведь велико дело привычки!...) они показались бы ему чересчур тяжелыми и грустными, а он и так, бедняга, очень склонен к пессимизму... но главное, что за год, за два он не успел бы приспособиться к жизни среди людей, где большинство безличных, идущих вслед за испорченным и гадким меньшинством, и где так страшно мало истинно-хороших людей. ... Известная доля нравственной эластичности необходима для того, чтобы человек мог жить в современном обществе. Гимназия ... незаменима, как фактор, вырабатывающий эту эластичность» [23, с. 63].

Сторонники системы свободного воспитания относились к такой позиции крайне отрицательно, доказывая, что родители, смирившись с необходимостью обучения ребенка в традиционной школе и занимаясь попытками ее «улучшения» (что, по их мнению, сделать совершенно невозможно), доводят до 
того, что «глубокая, внутренняя, тяжелая болезнь существующей школы, которая так или иначе признается и обществом, и правительством ... вгоняется еще больше внутрь, а некоторые внешние, слишком уж отвратительные язвы и нагноения ненадолго и обманчиво залечиваются» [24, с. 101]. В качестве единственно возможного пути выхода из создавшейся ситуации - отсутствия возможности отправить ребенка в «новую» школу - они предлагали родителям открыть ее для своих детей: «Если нет такой школы, какую вы хотите для своих детей, т.е. конечно, лучшую школу, то ее надо создать, и создать именно вам, не дожидаясь того далекого времени, когда у всех будет самая лучшая школа... (выделено в источнике-прим. авт.)» [24, с. 100].

Передовые педагоги, да и часть родителей не считали эти предложения фантастикой. В конце концов, если нет другого выхода, то «нельзя ли нескольким людям посвятить свою жизнь на то, чтобы оградить доверенных им детей от существующего зла, создать для них такой мирок, где бы они могли расцветать и крепнуть, не заражаясь нашими пакостями, и где бы они, зная все то, что открыто лучшими представителями человечества о жизни, о благе и о назначении человека, - где бы они приобрели совершенно иной склад души, чем у нас» [9, с. 33]. В том, что мотив обучения собственных детей и младших родственников играл большую роль в открытии «передовых» школ, можно убедиться, посмотрев списки учеников первого набора того или иного учебного заведения: там обязательно встретятся фамилии хозяев учебного заведения [16].

Приблизительно по данной схеме появилось в С.Петербурге одно из самых «передовых» учебных заведений - упомянутая выше женская Стоюнинская гимназия. Мысль об открытии средней школы для девочек впервые появилась у Марии Николаевны Стоюниной в 1879 г.: «Я тот час сказала об этом своему мужу (известный педагог Владимир Яковлевич Стоюнин - прим. авт.). Ему пришлась по душе моя мысль, - но он не знал еще, насколько крепко она утвердилась во мне, и потому отвечал, что согласится содействовать мне только в том случае, когда я через год - еще раз повторю ему о своем намерении» [25, л. 1]. Ситуация изменилась в 1881 г., когда их старшая дочь Лина достигла возраста первоначального обучения. И, как прямо заявляли родители, «для нее и был открыт младший приготовительный класс», положивший начало будущему учебному заведению. Аргументировала же мать учреждение школы следующим образом: «...мы с Владимиром Яковлевичем хотели видеть наших детей прежде всего «людьми», а так как мы не верили тому, что существующие казенные школы могут дать им такое воспитание, такой «закал», мы и стали мечтать создать «свою» школу, которая помогла бы нам сделать из наших родных детей и из их сверстников «людей» - настоящих, честных и работоспособных граждан своей Родины» [26, л. 3-4].

Если в последней четверти XIX в. подобное решение проблемы образования своих детей приходило в голову лишь отдельным «новым идейным родителям», то в начале XX в. даже в самых отдаленных регионах Российской империи уже существовали родительские кружки, собственными силами и на соб- ственные средства открывавшие «свободные» школы для своих детей. Начинались они, как правило, с детского сада или приготовительного класса, в который собирались дети основателей учреждения, а затем разрастались по мере перехода детей из класса в класс и поступления в учебное заведение новых учащихся. Позитивный опыт «передовых» школ постоянно пропагандировался в педагогической прессе, находя все новых и новых последователей [27-30].

Сам подход к открытию «передовых» школ неверие в возможность существующей образовательной системы сделать из детей «настоящих граждан своей Родины» - предопределил оппозиционный характер этих элитных учебных заведений как с точки зрения внешней организации учебного процесса, так и внутреннего его содержания. Особенностями организации учебного процесса в Стоюнинской гимназии были следующие: «Специальных воспитательниц «классных дам», - вспоминала уже упомянутая выше ученица школы О. Яфа, - в нашей гимназии не было: воспитательские функции считались неотъемлемыми от преподавателя любого предмета и вменялись в обязанность каждого педагога. Отметок не полагалось: педагог должен прививать детям интерес и любовь к знанию, которые в таком случае и будут достаточным и гораздо более благородным стимулом к учебной работе. Лишь в конце каждого полугодия мы получали ведомости, где отмечались наши успехи по предметам, но не цифрами, а словами: «удовлетворительно», «хорошо», «очень хорошо». Оценка ниже удовлетворительной подробно детализировалась родителям, чтобы они знали, на какие слабые места и пробелы в знаниях их детей они должны направить свою помощь» [19, л. 9-9 об.].

Аналогичным образом организовывался образовательный процесс в другом элитном учебном заведении - Тенишевском училище, намеревавшемся «порвать всякую связь» со старой школой. План и программы были «совершенно переработаны. Из них исключено все ненужное... не требовалось более никаких внешних мер для усвоения предметов: ни баллов, ни наград, ни наказаний. Отсутствие прав для учащихся считалось одним из важных условий для развития действительного интереса К науке» $[31$, c. 23].

Даже внешне дети, посещавшие «передовые» школы, отличались от своих сверстников, обучавшихся в казенных. Во многих подобных учебных заведениях вообще не устанавливалось обязательной формы, а рекомендовалась лишь «легкая и короткая одежда», т.к. ежедневно дети проводили не менее часа играя на свежем воздухе и еще два часа в мастерских, занимаясь ручным трудом [31, с. 26-32]. В Стоюнинской же гимназии, хотя официально форма существовала, но для детей, которые не хотели ее носить, допускались серьезные послабления: «Ходили все девочки в голубых сатиновых халатах и легких тапочках, которые оставались в гимназии. Стоюнинки гордились своей гимназией и своей свободой обращения. Детей не стесняли. Мне, - вспоминала Н.И. Гаген-Торн, - позволяли под халатом носить привычные мне штаны и матроски. Мы с Татой Глебовой и Мухой Гвоздевой, трое из нашего класса, ходили одетые мальчиками» [32].

Эти внешние проявления свободы находились в неразрывной связи с действовавшей внутри школы, 
далеко выходившей за пределы допустимого свободой поведения. Отдельные педагоги и целые педагогические коллективы, реализуя принцип соблюдения прав личности, предоставляли детям полную свободу движений, шума и иных нарушений тишины и порядка. Они надеялись, что постепенно все эксцессы сами собой исчезнут. В результате дети, «получая излишнюю самостоятельность, не только не учились владеть собой, но и совершали антиобщественные поступки» [33].

Интересный эпизод из жизни еще одной элитной, правда не столь передовой, как Стоюнинская, школы, - гимназии Оболенской, описывает Н.И. ГагенТорн. Важно, что девочка поступила в данное учебное заведение, уже имея опыт обучения в гимназии Стоюниной и, соответственно, выработанную там привычку к полной свободе. Итак, в новой школе учительница прочла вслух в классе сочинение школьницы, иронически подчеркивая все его неровности. «Класс хохотал. Я не была уязвлена или обижена, нет, я взбунтовалась. Распахнув двери, я закричала: Бэби, кататься! И толстая Бэби (девочка) с топотом прискакала ко мне. Размахивая мечом-линейкой, я вскочила к ней на спину, и мы помчались по залу. Конечно, вскоре нас поймали и отправили в директорскую». По этому поводу был созван педагогический совет, но решалась не судьба девочек, а судьба учительницы, которая посмеялась над свободным творчеством ученицы, так как «интеллигентные воспитатели больше всего думали о ранимости души ребенка и боялись его обидеть». По решению совета Ольгу Владимировну (учительницу) заставили публично извиниться перед Н.И. Гаген-Торн. Характерно, что спустя годы мемуаристка не смогла однозначно оценить этот педагогический опыт: «Надо ли было это делать ей? Надо ли было так решать на педагогическом совете? Вероятно, да! Для нервной и чуткой девочки это могло действительно стать серьезной травмой. И они - гуманные и вдумчивые учителя - были правы, опасаясь за душу ребенка. Но для меня, вероятно, нужно было другое - серьезный и вдумчивый разговор, а не это публичное извинение. Оно только добавило мне и без того достаточно сильное чувство «победительности», уверенности в том, что я могу и сумею сделать то, что захочу. Я не была ни избалованной, ни злой, но во мне жила абсолютная уверенность в своей свободе» [32].

Вместе с тем передовые школы не отрицали необходимость воспитания самостоятельности и ответственности. Достичь этого, как явствует из протокола заседаний педагогического совета гимназии М.Н. Стоюниной, можно было следующими действиями: «...Чтобы приучить детей строго относиться к исполнению своих обязанностей, установлено дежурство, которое состоит в следующем: 1) утром, перед первым уроком, дежурный должен намочить губку, раздать доски, осмотреть, у всех ли наточены грифеля, если нет, то принести их учительнице, 2) вытереть классную доску и распорядиться, чтобы счеты стояли на месте, 3) позаботиться, чтобы был мел и стул для учительницы, 4) прочитать молитву перед учением, 5) целый день соблюдать порядок в классе» [34, л. 6]. В качестве дополнительной формы воздействия применялось активное участия учеников во внеклассной работе: «Работа по устройству круж- ков, спектаклей, вечеров, экскурсий, игры и так далее. Исполнение этих обязанностей возлагается на учеников, выбранных классом из своей среды» [35, л. 8].

Апологеты свободного воспитания были убеждены, что если предлагаемых мер оказывается не достаточно и дисциплина «расстраивается», то виноват в этом исключительно наплыв в новую школу учеников, уже имевших опыт обучения в казенных учебных заведениях, которые, как отмечалось, например, в протоколе заседания педагогического совета гимназии К. Мая за 1908-09 гг., приходят «с очень слабой подготовкой, а главное, казенными привычками: они не слушают на уроках, не занимаются дома и вносят в класс нежелательное настроение» [36, л. 33].

Усиленно взращивали «свободу» сторонники свободного воспитания и в ходе самого учебного процесса, ведя с детьми «передовые разговоры». Вот, например, воспоминания о содержании занятия, проведенного М.Н. Стоюниной с ученицами старшего класса в 1893 г.: «...она не столько беседовала с нами, а рассказывала с горячим увлечением о Герцене, его журнале «Колокол», на обложке которого были изображены барельефы профилей пяти повешенных декабристов, о друге Герцена Огареве, о поколении русских девушек и женщин 60-х и 70-х годов, не жалея сил боровшихся за право русских женщин на труд, на высшее образование. Сами для себя они мало что добились, хотя некоторые из них и стали врачами, педагогами, переводчицами, художниками, - но они добились всего этого для сменивших их, следовавших за ними поколений, для вас» [26, л. 2-3].

Принцип «оппозиционности» становился важным фактором при приеме новых учителей передовых школ. Так, известная общественная деятельница и историк О.А. Добиаш-Рождественская была уволена из гимназии Л.С. Таганцевой, где она «проводила ученические собрания, помогала учащимся в выработке петиций». Однако в учебном заведении Стоюниной ей предложили работу «не взирая на её идейные убеждения». Приняты были и девушки, последовавшие за Ольгой Антоновной [37, л. 40].

О.А. Добиаш-Рождественская сразу вписалась в коллектив, формируя общественную позицию школьниц не только в ходе уроков, но и на занятиях литературного кружка. Е.Н. Чехова описывала, насколько это увлекало девочек: «Темой кружка была: «Женщина в русской литературе». Мы начали с княжны Марьи в «Войне и мире» Толстого, через «Что делать?» Чернышевского перешли к Герцену и женщинам-революционеркам в «Андрее Кожухове» Степняка-Кравчинского... Мы собирались в гимназию вечером через субботу с таким интересом и радостью, точно это был праздник» [37, л. 56].

Очевидно, что хотя среди учащихся и могли оказаться те, чьи родители отдали детей в «престижные» школы, не предполагая, какое обучение и образование их там ждет, но подавляющее большинство, преодолевая немалые материальные и моральные трудности для определения детей в эти учебные заведения, заранее поддерживали взгляды и подходы к воспитанию местных преподавателей. А это означало, что и дома, в семье, велись «свободные» разговоры, при которых присутствовали, а возможно, и участвовали дети. 
Результат подобного семейно-школьного и однозначно «оппозиционного» существующей системе власти воспитания не мог не сказаться на школьниках. В элитных учебных заведениях, более чем в каких-либо других в России конца XIX - начала XX в., «имело место имплицитное нигилистическое воспитание подростков: ... политизация ученической среды, «выталкивание» подростков во взрослую жизнь, сочувствие терроризму становилось нормой жизни...» [38, с. 240-241].

Очень яркую картину того, как сами воспитуемые представляли себе достойного «человека» и «гражданина», находим в воспоминаниях О. Яфа:

Рубеж 80-х - 90-х гг. XIX в. На переменке девочки-старшеклассницы, учащиеся Стоюнинской гимназии, обсуждали животрепещущие для них вопросы: «Что такое подвиг?» и «Настоящее самопожертвование»... «После минутного молчания раздался тихий голос Мани Станюкович:

- Что такое истинное самопожертвование? Мне рисуется большая городская площадь, запруженная народом. Посреди площади сооружен эшафот и толпа собралась смотреть на казнь. Привозят приговоренного: молодого революционера. И вот вдруг объявляют (это, конечно, невероятно, но ведь фантазировать можно?) ... что этому человеку будут дарованы жизнь и свобода, если в этой толпе найдется хоть один, который согласиться, вместо него, сложить свою голову на плахе. Толпа вполне сочувствует революционеру, но ... умереть за него? Таких не ... находится. Молодого человека ведут на эшафот, подводят к плахе... И вдруг из толпы раздается голос: - Я хочу умереть за него: верните ему жизнь и свободу!». Обдумывая этот пример «истинного самопожертвования», остальные замолчали. Всех их, скорее всего, поразила та же мысль, что и автора приведенных воспоминаний, написанных на основе дневника - «Как жаль, что не я сказала это, ведь я думаю так же» [19, л. 91 об. - 92].

Таким образом, «новые идейные» родители и созданные передовыми педагогами при их активном участии и поддержке элитные школы не только оказывали существенное влияние на формирование эталона свободного воспитания, но и способствовали укоренению в дворянско-интеллигентной среде особой интеллигентской оппозиционности, принимающей, а то и поддерживающей все средства в борьбе «граждан» за «свободу». Во многом благодаря целенаправленным усилиям «семьи и школы» «самой благоприятной средой для культивирования героизма» становилась «ученическая среда» и российская молодежь с ранней юности втягивалась «в политические интриги и дрязги различных группировок и партий, доходя зачастую до предела» [39, с. 91-92]. Вместе с тем группа «новых идейных» родителей не могла составлять к началу XX в. действительно массового явления. Ведь осуществляемый ими опыт воспитания предполагал слишком большие расходы на каждого ребенка, что в массе своей было совершенно недоступно рядовому российскому дворянину. Однако, обладая значительным интеллектуальным, материальным и информационным багажом, эта группа родителей и педагогов распространяла свое влияние и на остальное образованное население, и даже на министерство народного просвеще- ния, которое в угоду передовой педагогике соглашалось на повсеместное внедрение отдельных идей свободного воспитания в средней школе. Все это в комплексе становилось одним из существенных факторов революционизации российского общества.

\section{Список литературы:}

1. Пирогов Н.И. Вопросы жизни // Избранные педагогические сочинения. М.: Педагогика, 1985.

2. Веременко В.А. Дети в дворянских семьях России (вторая половина XIX - начало XX в.). СПб.: ЛГУ им. А.С. Пушкина, 2015. 204 с.

3. Senex. К дефектам средней школы // Русская школа. 1905. № 5/6.

4. Горбунов-Посадов И. Несколько вступительных слов // Свободное воспитание. 1907/8. № 1. С. 2-9.

5. Хорошие и плохие учителя по отзывам учащихся // Свободное воспитание. 1907/8. № 3. С. 89-93.

6. Эльсландер Ж. Новая школа // Свободное воспитание. 1907/8. № 1.

7. Дурылин С. Из книги и жизни // Свободное воспитание. 1907/8. № 1.

8. Ганина С.А. Концепция свободного воспитания: опыт социально-философской рефлексии феномена детства // Общество. Среда. Развитие (Terra Humana). 2012. № 1. C. 183-186.

9. Попов Е. Письма о воспитании // Свободное воспитание. 1907/8. № 8 .

10. Бобков Д.А. Исторические аспекты развития нравственного воспитания в России в XIX - начале XX веков // Современные проблемы науки и образования. 2012. № 5.

11. Надеина К.Е., Гвоздева Н.А. Развитие идей гражданственности и гражданского воспитания в отечественной педагогической мысли второй половины XIX - начала XX в. // Интеграция образования. 2010. № 3. С. 47-51.

12. Беленцов С.И. Воспитать гражданина: осмысление исторического опыта русской педагогики и школы (конец XIX - начало XX вв.) // Проблемы современного образования. 2014. № 1. С. 51-62.

13. Веременко В.А. Факторы, определявшие условия жизни школьника в дворянско-интеллигентских семьях России в конце XIX - начале XX в. // Материнство и отцовство сквозь призму времени и культур: материалы Девятой междунар. науч. конф. РАИЖИ и ИЭА РАН, 13-16 октября 2016 г., Смоленск: в 2 т. / отв. ред. Н.Л. Пушкарева, Н.А. Мицюк. Смоленск-М.: Изд-во СмолГУ, ИЭА РАН, 2016. Т. 2. C. 405-408.

14. Рутцен В. Свобода школы, или свобода от школы // Русская школа. 1906. № 5-6.

15. Веременко В.А. Женщины в русских университетах (вторая половина XIX - начало XX вв.). СПб.: Изд-во ВАШ, 2004. 150 с.

16. Школа Е.С. Левицкой в Царском Селе. Программа для поступающих. СПб., 1903.

17. Веременко В.А. Проблемы среднего совместного образования в России (школа Е.С. Левицкой в Царском Селе) // 300 лет Царскому селу: сб. научных статей / отв. ред. В.А. Веременко. СПб.: ЛГУ им. А.С. Пушкина, 2010. С. 63-67.

18. Отдел рукописей Российской национальной библиотеки (ОР РНБ). Ф. 163 - Второвы. Д. 314.

19. ОР РНБ. Ф. 163 - Второвы. Д. 316. 
20. Институт русской литературы Российской Академии наук (ИРЛИ РАН) (Пушкинский дом). Ф. 445 - Е.С. Зарудная-Кавос. Д. 43.

21. Институт русской литературы Российской Академии наук (ИРЛИ РАН) (Пушкинский дом). Ф. 445 - Е.С. Зарудная-Кавос. Д. 44.

22. Веременко В.А. Пансионы в России во второй половине XIX - начале XX в. // Вестник Ленинградского государственного университета им. А.С. Пушкина. 2015. № 3. С. 33-39.

23. А-ская. Из записок матери // Свободное воспитание. 1907/8. № 10.

24. Дурылин С. Общественное педагогическое творчество // Свободное воспитание. 1907/8. № 9. C. $100-103$.

25. ОР РНБ. Ф. 744 - В.Я. Стоюнин. Д. 302.

26. ОР РНБ. Ф. 163 - Второвы. Д. 370.

27. Веременко В.А. Детские сады и вопрос о социализации детей дошкольного возраста в дворянско-интеллигентских семьях России второй половины XIX - начала XX в. // История повседневности. 2017. № 3 (5). С. 99-111.

28. М.К. Опыт семейной школы в Москве // Свободное воспитание. 1907/8. № 1. С. 51-59.

29. Горбунов-Посадов И. Заметка о московском «Кружке совместного воспитания и образования детей» и «Детском саде М.А. Гуцевич» // Свободное воспитание. № 6. С. 109-111.
30. А.Т. Еще одна попытка свободного воспитания и образования // Свободное воспитание. 1908/1909. № 1. С. 5-32.

31. Соломин Е. Физическое воспитание и развитие самодеятельности учащихся в Тенишевском училище (в СПб.) // Свободное воспитание. 1909/10. № 4. C. 23-34.

32. Гаген-Торн Н.И. Memoria / сост., предисл., послесл. и примеч. Г.Ю. Гаген-Торн. М.: Возвращение, 1994. 415 с.

33. Беленцов С.И. Юношеское самоуправление: укрепление дисциплины или формирование сознательности (исторический аспект) // Вестник ПСТГУ. Серия 4: Педагогика. Психология. 2013. № 4 (31).

34. ОР РНБ. Ф. 744. Д. 347.

35. Центральный государственный исторический архив г. Санкт-Петербург (ЦГИА СПб.). Ф. 144. ОП. 1. Д. 77.

36. ЦГИА СПб. Ф. 144. ОП. 1. Д. 41.

37. ОР РНБ. Ф. 254 - Добиаш-Рождественская О.А. Д. 480.

38. Шик С.В. Развитие «внутреннего человека» у подростков начала XX века как педагогическая проблема // Сибирский педагогический журнал. 2009. № 3. С. 237-242.

39. Беленцов С.И. Духовно-нравственные основы гражданского воспитания юношества в России конца XIX - начала XX в. // Вестник ПСТГУ. Серия 4: Педагогика. Психология. 2013. № 28 (1).

\section{UPBRINGING OF A REVOLUTIONARY: THE CONCEPT OF «FREE EDUCATION» IN ELITE SCHOOLS IN LATE XIX - EARLY XX CENTURIES RUSSIA}

(C) 2018

Veremenko Valentina Alexandrovna, doctor of historical sciences, professor, head of Russian History Department Pushkin Leningrad State University (Pushkin, Saint Petersburg, Russian Federation)

Abstract. The paper explores the influence of pedagogical concept of «free education» on the formation of the world view of adolescents from the noble-intelligent families of Russia at the end of the XIX - beginning of the XX century. Attention is drawn to the fact that this pedagogical setup could be fully realized only in elite educational institutions. It is concluded that the «new ideological parents» and «advanced schools» carried out a single educational approach, focused on formation of a special intelligentsia opposition, accepting, or even supporting, all means in the struggle of «citizens» for «freedom». Despite the fact that the group of «new ideological parents» could not have been a mass phenomenon by the beginning of the XX century, it, at the same time, spread its influence both to the rest of educated population of the country and to the Ministry of Public Education, which, in favor of advanced pedagogy, agreed on the widespread introduction of individual ideas of free education in secondary schools. As a result of purposeful efforts of family and school, young people from the early youth were drawn into political activity, which became one of the essential factors of the revolutionization of the Russian society.

Keywords: Russia; early XX century; nobility; intelligentsia; family and school unity; free education; civic education; adolescents; elite educational institutions; teachers; new ideological parents; oppositionism; revolutionization.

УДК 94 (73)

Статья поступила в редакцию 19.11.2017

\section{ПЛАН ГОЭЛРО В ОЦЕНКЕ ПРЕССЫ США И ВЕЛИКОБРИТАНИИ 1920-1929 ГОДОВ} (C) 2018

Буранок Сергей Олегович, доктор исторических наук, профессор кафедры всеобщей истории, права и методики обучения Самарский государственный социально-педагогический университет (2. Самара, Российская Федераџия)

Аннотащия. В данной статье предпринято исследование того, какое место и значение занимал план электрификации России и его реализация в общественном мнении Великобритании и США. Изучение информационной кампании вокруг плана ГОЭЛРО в контексте методов и подходов исторической имагологии имеет свою специфику и значение: во-первых, это даёт возможность установить новые, неизвестные факты; вовторых, определить уровень информированности «другого» (в данном случае американского) общества о советской энергетике; в-третьих, понять, какое место информация о плане ГОЭЛРО занимала в США и Великобритании в системе построения образа СССР, образа «советской энергетической революции», для решения 